\title{
Sufteutatifde Sammluma
}

bex iII

Elfak-Pothringen geltenden Gerebe. 



\title{
Syftemntildo Sammlung
}

ber in

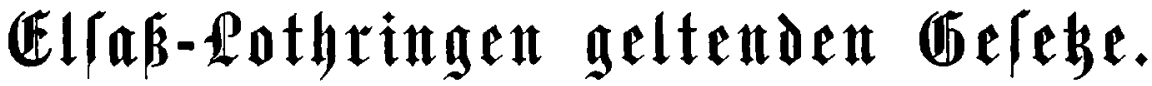

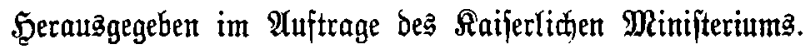

Brweiter $\mathfrak{B a n t o}$.

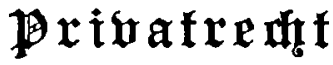

\author{
bearbeitet boll

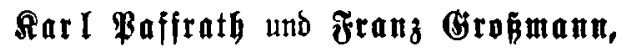

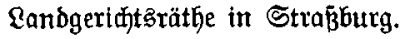

3roite $\mathfrak{A b t h e i l u n g . ~}$

Mit Bejamtregijter zu Band I und Il.

Strapara

Berlag von $\Re a r l ~ \mathfrak{J}$. Trübner.

1901. 
Straß̧burg, Drut bon $\mathfrak{R}$. DuMto nt=Sđjauberg. 